\title{
Determination of Magnesium in Whole Blood and Serum of Ischemic Heart Disease (IHD) Patients by Flame Atomic Absorption Spectrometry
}

\author{
Hassan T. Abdulsahib \\ Chemistry Department, College of Science, University of Basra, Basra, Iraq \\ E-mail:lolaby2005@yahoo.com \\ Received October 10, 2011; revised November 15, 2011; accepted November 23, 2011
}

\begin{abstract}
Flame atomic absorption spectrometric determination of magnesium in whole blood and serum of ischemic heart disease patients and control with different ages and sex was proposed. The limiting interfering phosphate/magnesium ratio have been estimates. $2 \% \mathrm{w} / \mathrm{v} \mathrm{AlCl}_{3} \cdot 6 \mathrm{H}_{2} \mathrm{O}$ was found to be very influential in removing phosphate interference effects. The detection limit was $0.065 \mu \mathrm{g} / \mathrm{ml}$. Magnesium added to blood and serum sample, and carried through this method may be recovered completely $(96 \%-100 \%)$ recovery percentage. The suggested method is simple, fast and selective. The statistical analysis of magnesium levels in blood and serum showed that blood and serum magnesium levels in patients were lower than magnesium contents of control group. Magnesium levels in blood and serum of males were significantly higher than females and the magnesium levels were age independent. These findings indicate that there was an association between blood and serum magnesium deficiency which can induce an entire array of path physiological phenomena known to be important in ischemic heart disease.
\end{abstract}

Keywords: Magnesium, Whole Blood, Serum, Ischemic Disease, Atomic Absorption

\section{Introduction}

Magnesium is an essential micronutrient for humans and plays many important roles, of principal importance are its roles in the function of over 300 enzymes and in neuromuscular transmission [1]. Abnormal dietary deficiency of $\mathrm{Mg}$ as well as abnormalities in $\mathrm{Mg}$ metabolism play important roles in different types of heart diseases such as ischemic heart disease [2]. Magnesium deficiency has been associated with most of the major risk factors for atherosclerotic coronary artery disease, coronary artery spasm, and coronary artery thrombosis and many studies in large population have shown that higher intake of this mineral is associated with lower risk of high blood pressure, stroke, and ischemic heart disease [3].

There is growing evidence that magnesium deficiency is important in the pathogenesis of ischemic heart disease [4]. In addition to the indirect epideomologic evidence, there is experimental evidence that supports the role of magnesium deficiency in ischemic heart disease, autopsies of patients who died from ischemic heart disease have shown lower cardiac magnesium levels than autop- sies of those who died from other causes [5].

Bersohn [6] also commented on the much greater susceptibility to ischemic heart disease of the African whites than the blacks and considered the higher serum $\mathrm{Mg}$ of the blacks a possibly significant factor.

Magnesium deficiency may usually be reflected in low-magnesium diet, blood loss, excessive sweating, drug and/or alcohol abuse or due to certain medication use (such as loop diuretics and thiazides, cytotoxic drugs, aminoglycosides, digoxin, steroids), or some physiological conditions of over utilization of magnesium such as pregnancy or infancy growth. Mental stress can also lead to magnesiuresis due to high serum adrenalin [7].

Several analytical methods are normally needed for the determination of magnesium in whole blood and serum [8]. Even with determination of this element by atomic absorption spectroscopy, various dilutions and some anti interference reagents are required [9]. In this work, a sensitive method for the determination of magnesium in serum and whole blood is introduced, In which, the interference effects of phosphate was completely removed by the addition of $\left(2 \% \mathrm{w} / \mathrm{v} \mathrm{AlCl}_{3} \cdot 6 \mathrm{H}_{2} \mathrm{O}\right)$. The 
procedure is relatively simple, rapid and the addition of anti interference reagents could easily lead to real values. Therefore, the present study was elucidated some physiological and biochemical actions of magnesium in the mechanism of cardiac disease by the determination of magnesium in whole blood and serum samples of ischemic heart disease patients using a flame atomic absorption spectrometric method.

\section{Materials and Methods}

\subsection{Apparatus}

Ashimadzu atomic absorption spectrophotometer model (AA-630-12) was used with an air-acetylene burner (slot dimensions $100 \times 0.62 \mathrm{~mm})$. Instrument settings were: lamp current, $10 \mathrm{~mA}$; wave length, $285.2 \mathrm{~nm}$; slit width, $0.2 \mathrm{~nm}$. These conditions were maintained constant throughout the measurements.

\subsection{Reagents}

Magnesium stock solution Add $200 \mathrm{mg}$. of distilled magnesium metal to a $100 \mathrm{ml}$ volumetric flask. Dissolve using the minimal quantity of hydrochloric acid. Dilute to volume with deionized water. Magnesium working standards: Transfer $(0.5-5) \mathrm{ml}$ of the stock solution to ten a $100 \mathrm{ml}$. volumetric flask and dilute to volume with deionized water. This gives a concentrations of (10 - 100) $\mu \mathrm{g} \mathrm{Mg} / \mathrm{ml}$.

Aluminum chloride solution Dissolve $8 \mathrm{gm}$. of reagent-grade aluminum chloride hexahydrate in $100 \mathrm{ml}$. of deionized water.

\subsection{Preparation of Samples}

Thirty one patients with ischemic heart disease fulfilling the Clinical care unit in Al-sader technical hospital. Twenty three aged and sexes matched control group were taken from apparently healthy people attending the hospital, for pre-emplyment examination .For the groups, patients and control, serum and whole blood magnesium were measured upon presentation before starting treatment.

Pipet $1 \mathrm{ml}$ of serum into a digestion tube. Add $2 \mathrm{ml}$ of concentrated nitric acid and 2 drops of concentrated perchloric acid. Place the tube in a hotplate at $130^{\circ} \mathrm{C}$ to $150^{\circ} \mathrm{C}$. The initial temperature of hotplate is $120^{\circ} \mathrm{C}$. When the volume is reduced to about $1 \mathrm{ml}$, turn the hot plate to high $180^{\circ} \mathrm{C}$. Continue the digestion until the perchloric acid fumes. Add 3 drops of nitric acid and leave on the solution until dry salts start to form. Remove the tube from the hotplate and wash down the walls of the tube with approximately $2-4 \mathrm{ml}$. of deionized water.
Add 1 drop of $8 \%$ aluminum chloride. Place the tubes in a boiling water bath for $5 \mathrm{~min}$. Remove, cool, and dilute to $12.5 \mathrm{ml}$. with deionized water. Centrifuge and transfer two $2 \mathrm{ml}$ aliquots of the supernatant liquid.

\subsection{Statistical Analysis}

The statistical analysis were carried out using two-way analysis of variance with unbalanced repeated measurements .Statistical significance between individual time points was made by using Revised Least Significant Difference (RLSD) test. The probability level for significance was $5 \%$ less.

\section{Results and Discussion}

\subsection{Interferences}

The interference of ions present in serum in concentrations greater than $0.5 \mu \mathrm{g} / \mathrm{ml}$. was considered. These include $\mathrm{Fe}(0.1-1.8 \mu \mathrm{g} / \mathrm{ml}), \mathrm{Cu}(1.96-2.63 \mu \mathrm{g} / \mathrm{ml}), \mathrm{Ca}(90$ - $110 \mu \mathrm{g} / \mathrm{ml}), \mathrm{NH}_{4}(1.43$ - $3.0 \mu \mathrm{g} / \mathrm{ml}), \mathrm{P}(85-155 \mu \mathrm{g} / \mathrm{ml})$, $\mathrm{S}(22-56 \mu \mathrm{g} / \mathrm{ml}), \mathrm{Cl}(3500-3710 \mu \mathrm{g} / \mathrm{ml})[10], \mathrm{Zn}(1.25$ $\mu \mathrm{g} / \mathrm{ml})[11]$. The sensitivity of the method makes it possible to use an aliquot equivalent to $1 \mathrm{ml}$. of serum and the quantities of ions checked were based on these relationships. The interference, which appears to be inconsistent, is compensated by adding it to the magnesium standard at the time of analysis. Phosphate was found to cause the major interference, as shown in Figure 1. In an effort to understand the nature of this interference, this effect cannot be due exclusively to a magnesium phosphate complex since aluminium is affected by phosphate even in the absence of magnesium. The interference is not dependent on ionic strength.

Investigations to mask or remove the phosphate led to

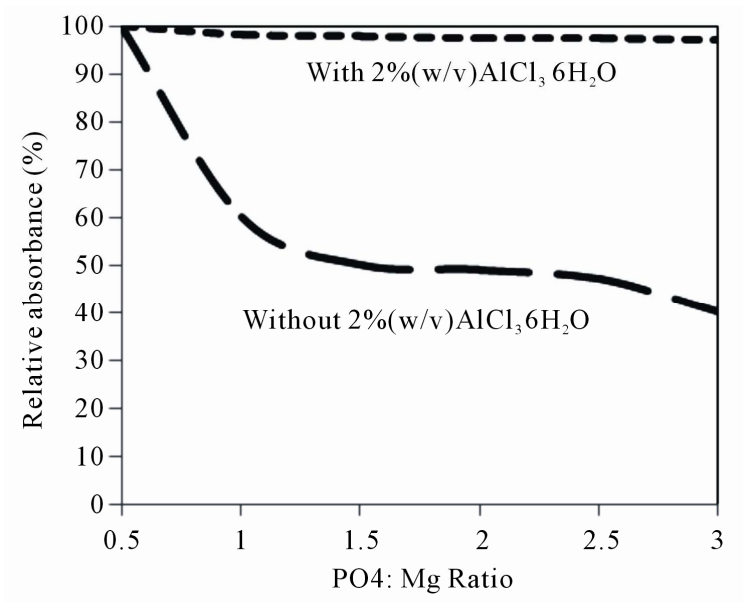

Figure 1. Interferences effects of phosphate on $(1 \mu \mathrm{g} / \mathrm{ml})$ magnesium absorbance signal. 
the discovery that aluminum effectively precipitates all the phosphate. This was confirmed by spectrographic analysis. The excess precipitant comes down as the hydroxide. At least 1 mole of aluminum is required per mole of phosphorus but large excesses must be avoided. Boiling is necessary for complete precipitation and reduces the inclusion of magnesium in the precipitate. This controlled precipitation is complete enough to avoid such problems. At the levels used in the above experiment, the effect of combinations of calcium phosphate on the absorbance of magnesium was completely eliminated by addition $2 \%(\mathrm{w} / \mathrm{v}) \mathrm{AlCl}_{3} \cdot 6 \mathrm{H}_{2} \mathrm{O}$ as shown in Table 1.

\subsection{Digestion}

Protein must be removed to avoid precipitation in the acid medium during measurements. Wet-ashing seemed to be the most feasible approach. It was found that $1 \mathrm{ml}$. of serum could be completely digested with minimum amounts of nitric and perchloric acids provided combustion tubes were used. In order to remove ammonium salts which form during the breakdown of protein, a few additional drops of nitric acid are added to the sample toward the end of the digestion. All chlorides are volatilized during this digestion. If the hot plate is preheated to digestion takes about $3 \mathrm{hr}$.

\subsection{Precision and Recoveries}

The average deviation of 10 determinations on a single serum sample was $\pm 3.47 \%$ with 5 of these determinations having a variability under $2 \%$. Recovery studies were made by adding known quantities of magnesium to a serum, the results of these experiments, which are summarized in Table 2, indicate that the over all recovery in the analytical process is $96.0 \%-100 \%$.

\subsection{Whole Blood and Serum Magnesium Measurements}

Hypomagnesemia (defined as concentration of magne

Table 1. Effect of $(2 \% \mathrm{w} / \mathrm{v})$ Aluminium chloride on magnesium atomic absorption signal in whole blood samples.

\begin{tabular}{ccc}
\hline \multirow{2}{*}{$\begin{array}{c}\text { Whole blood } \\
\text { samples No. }\end{array}$} & \multicolumn{2}{c}{ Mean of absorbance } \\
\cline { 2 - 3 } & With $\mathrm{AlCl}_{3} \cdot 6 \mathrm{H}_{2} \mathrm{O}$ & Without $\mathrm{AlCl}_{3} \cdot 6 \mathrm{H}_{2} \mathrm{O}$ \\
\hline 1 & 0.92 & 0.57 \\
2 & 0.33 & 0.11 \\
3 & 0.44 & 0.26 \\
4 & 0.82 & 0.29 \\
5 & 0.53 & 0.45 \\
\hline
\end{tabular}

sium in serum less than the normal range; $(0.7-1.1 \mathrm{mM}$, $1.7-2.5 \mathrm{mg} / \mathrm{dl}$ ) [12] is often not present in patients with chronic depletion of magnesium because of very slow equilibration of magnesium among serum and blood samples, which contains a small fraction of magnesium .These findings may explain at least part of the beneficial effect of administration of magnesium in some patients.

In our laboratory assessment of magnesium status usually begins with measurement of concentration of magnesium in the ischemic heart disease patients and control blood and serum samples Table 3 show their characters. All the measurements of the serum and blood samples subjected to statistical analysis using the independent samples RLSD-test to compare between measurements of the study groups( patients and control ), sex (males and females) and age groups (19 - 69 years).

The statistic results showed that there is a significant difference $(P<0.001)$ in magnesium levels in all the

Table 2. Recovery percentage of the direct method of whole blood samples.

\begin{tabular}{ccccc}
\hline $\begin{array}{c}\text { Sample } \\
\text { No. }\end{array}$ & $\begin{array}{c}\text { Mg content } \\
(\mu \mathrm{g} / \mathrm{ml})\end{array}$ & $\begin{array}{c}\mathrm{Mg} \\
\text { added, } \mu \mathrm{g}\end{array}$ & $\begin{array}{c}\text { Mg found } \\
(\mu \mathrm{g} / \mathrm{ml})\end{array}$ & $\begin{array}{c}\text { Recovery } \\
(\%)\end{array}$ \\
\hline \multirow{3}{*}{ I } & \multirow{3}{*}{55.7} & 25 & 79 & 97.89 \\
& & 50 & 103 & 97.44 \\
& & 75 & 125.5 & 96.00 \\
II & 42.2 & 25 & 65 & 96.00 \\
& & 50 & 92.2 & 100 \\
& & 75 & 116 & 97.2 \\
III & 33.9 & 25 & 154.0 & 98.97 \\
& & 50 & 82 & 97.7 \\
& & 75 & 107.5 & 98.71 \\
\hline
\end{tabular}

Table 3. Ischemic heart patients and charactors.

\begin{tabular}{|c|c|}
\hline Patients groups & Character \\
\hline Total & 31 \\
\hline Male & 13 \\
\hline Female & 18 \\
\hline Age range (years) & $19-69$ \\
\hline Median age (years) & 35.5 \\
\hline \multicolumn{2}{|c|}{ Associated diseases } \\
\hline Hypertension & 3 \\
\hline Diabetes Millets & 2 \\
\hline \multicolumn{2}{|c|}{ Drugs } \\
\hline Thazide diuretics & 1 \\
\hline B-blocker & 1 \\
\hline Captopril & 1 \\
\hline Insulin & 1 \\
\hline Daonil & 1 \\
\hline Aminoglycasides & 1 \\
\hline $\mathrm{Mg}$ containing antacid & 1 \\
\hline \multicolumn{2}{|c|}{ Symptoms } \\
\hline Vomiting & 6 \\
\hline Diarrhea & 1 \\
\hline
\end{tabular}


compared males and females serum and blood measurements as shown in Figure 2 and Figure 3 the concentration of magnesium whole blood and serum about $15 \%$ excess in males higher than in females. From these findings it would appear that while variation does occur in concentrations of magnesium in whole blood and serum with difference in sex, no definite pattern of distribution is present.

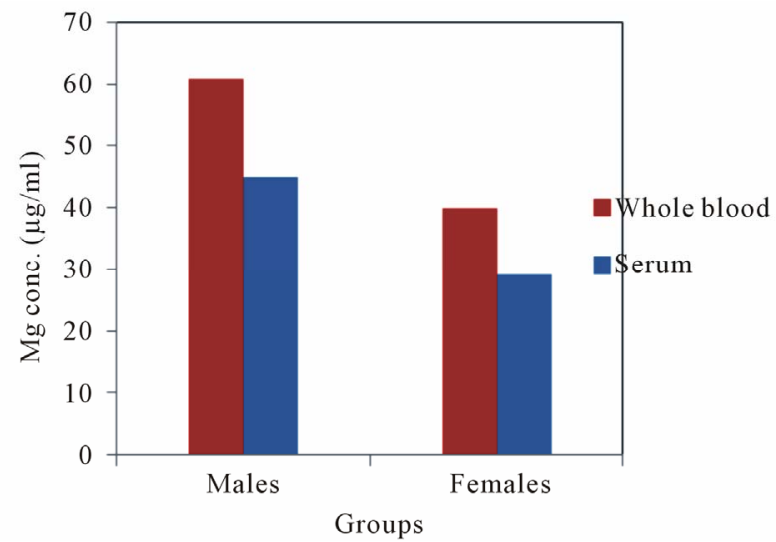

Figure 2. Mg concentrations $(\mu \mathrm{g} / \mathrm{ml})$ in whole blood and serum of control group.

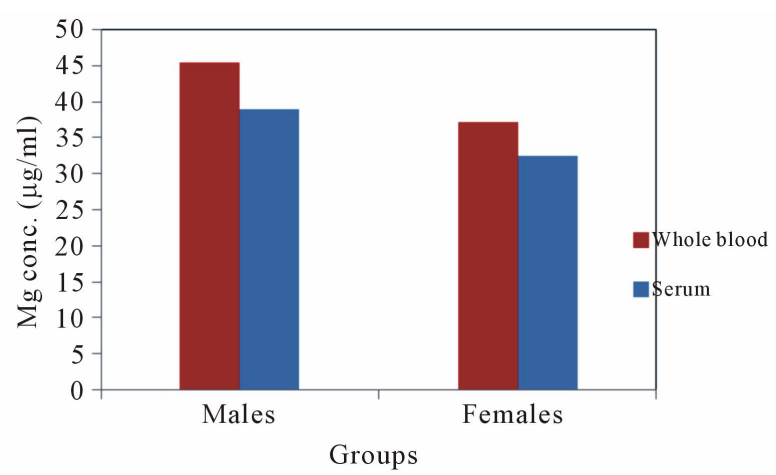

Figure 3. Mg concentrations $(\mu \mathrm{g} / \mathrm{ml})$ in whole blood and serum of IHD patients.

No statistically significant difference between age groups were seen in the mean value of magnesium concentrations in blood and serum for both patients and control. $(P<0.01)$ as shown in Figure 4 and Figure 5.

Figure 6 illustrates that there is a statistical relationship between the magnesium levels in whole blood and serum of ischemic heart disease patient and control group. The concentration of magnesium in patients serum and blood was about 35\% lower than in the control group.

Although this statistically significant difference, they imply that less than one percent of the variation in serum magnesium levels can be explained by differences in dietary intakes.. This relationship provides a quantitative

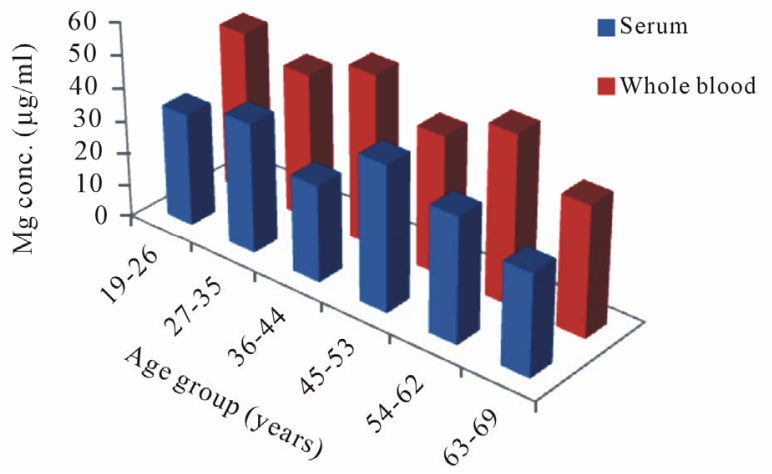

Figure 4. Mg concentrations $(\mu \mathrm{g} / \mathrm{ml})$ in whole blood and serum of control group.

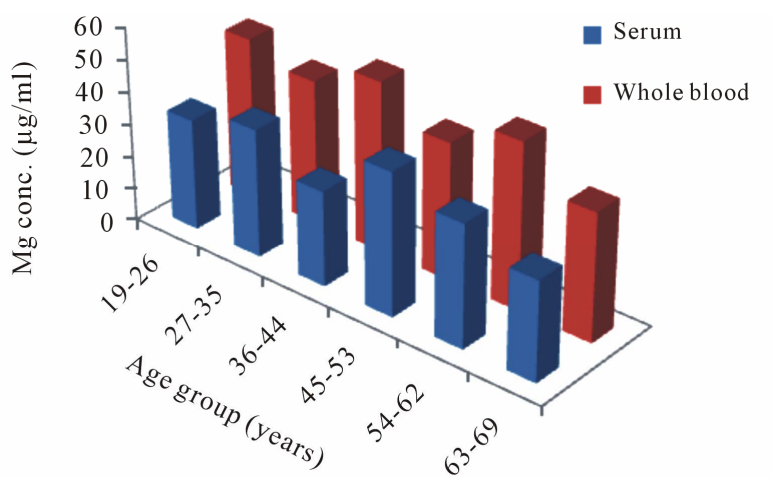

Figure 5. Mg concentrations $(\mu \mathrm{g} / \mathrm{ml})$ in whole blood and serum of IHD patients group.

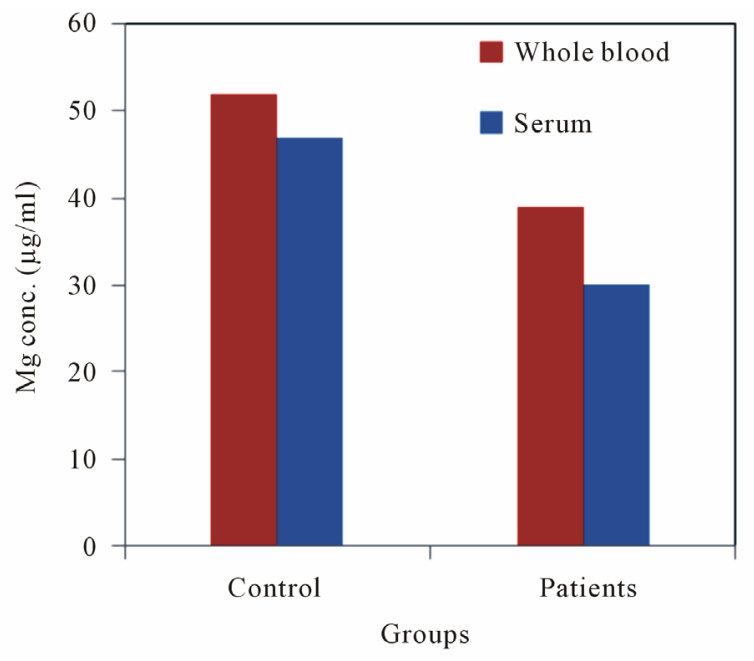

Figure 6. Mg concentrations $(\mu \mathrm{g} / \mathrm{ml})$ in whole blood and serum of IHD patients.

indication of the affinity of magnesium for a particular clinical fraction.

There may be a further explanation for the post-infarct decrease in serum magnesium concentration. Flink et al. [13] correlated the decrease of serum magnesium with a concomitant increase of free fatty acids. The rise in free 
fatty acid concentration is explained by an increased lipolysis which is induced by the enlarged catecholamine secretion involved in infarction. The same observation, a low magnesium concentration at increased free fatty acid concentration in serum was also found at ethanol with drawal in dogs [14] and after infusion of adrenalin in ewes [15]. Since the free fatty acids are able to bind magnesium it has been assumed that serum magnesium is thereby lowered [13]. Perhaps a more reasonable explanation for lowering of serum magnesium during increased lipolysis is an increased binding of magnesium by free fatty acids within the adipocytes. In vitro experiments with adipocytes support this view. Intact adipocytes showed an increased magnesium uptake after treatment with adrenalin [16].

Some aspects of the pathogenesis of cardiac disease are reviewed in the light of current knowledge of the physiological and biochemical actions of magnesium on heart function.. In human during myocardial infarction, there is a reduction of magnesium content even in non infracted areas of the myocardium, followed by a transient reduction of serum magnesium concentration. These effects are explained by the action of catecholamine on the myocardial cells, resulting in a loss of magnesium accompanied by a catecholamine-induced of many magnesium loss and/or increased lipolysis which binds magnesium as magnesium soaps in the adiposities. As a consequence serum magnesium may be decreased. A reduced serum magnesium concentration may enhance the action of catecholamines on the heart muscle as well as the action of vasopressive hormones, thus provoking contraction of coronary artery smooth muscle cells and favoring the development of arrhythmia.

Although many patients with chronic heart disease are magnesium depleted [17], a variety of superimposed stressors cause additional decreases in concentrations of magnesium in serum by redistribution [18]. Concentrations of magnesium in serum decrease significantly during Increasing concentrations of catecholamines also may have contributed to the decrease. Further decreases in concentrations of magnesium in serum are caused by additional hemodilution, binding to albumin in the pump prime, and redistribution secondary to catecholamine induced increases in concentrations of free fatty acid [19].

A considerable number of experimental, epidemiological and clinical studies are now available which point to an important role of $\mathrm{Mg}^{2+}$ in the etiology of cardiovascular pathology. In human subjects, hypomagnesemia is often associated with an imbalance of electrolytes such as $\mathrm{Na}^{+}, \mathrm{K}^{+}$and $\mathrm{Ca}^{2+}$. Abnormal dietary deficiency of magnesium as well as abnormalities in magnesium metabolism play important roles in ischemic heart disease.

Nonetheless, studies reporting $\mathrm{Mg}^{2+}$ assays on a vari- ety of tissues suggest that many patients with cardiovascular disease exhibit depletion of $\mathrm{Mg}^{2+}$ compared with healthy individuals [17].

A commonly cited explanation for the clinical efficacy of magnesium relates to its effect on the blood. Clinicians from the British Commonwealth [20] and Russia [21] have reported that magnesium therapy of patients with ischemic heart disease is associated with decreased $\beta$-lipoproteins, increased $\alpha$-lipoproteins, and increased lecithin/cholesterol ratio, or a drop in serum cholesterol.

The efficacy of magnesium in ischemic heart disease has been attributed to its antithrombotic activity, both enhancement of fibrinolysis and inhibition of coagulation being considered as mediating mechanisms. Substantially increased fibrinolytic activity of the blood of cardiac ischemia patients on $\mathrm{Mg}$ therapy has been reported by Parsons et al. [22]. This observation recalls the explanation of the efficacy of the earlier use of $\mathrm{Mg}$ in prevention of postoperative thrombosis [23] and in treatment of peripheral thrombotic disease [24]. The antithrombotic effect of magnesium has also been attributed to stabilization of platelet membranes [25] and to inhibition of platelet aggregation [26]. Supportive of the platelet membrane theory is recent work that has shown that $\mathrm{Mg}$ is necessary to maintain the disc shape of platelets [27]. Addition of $\mathrm{MgCl}_{2}$ to fresh human blood, under conditions that maintained electrolytes and enzyme systems as nearly normal as possible, resulted in reduction in the size and number of platelet clumps and an increase in the number of discrete platelets [28].

Unfortunately, it is difficult to evaluate the true human requirement of magnesium: depending age and protein intake the values given by various authors range from 0.1 to $0.4 \mathrm{mmole} / \mathrm{kg}$ per day [29]. This may be partially due to considerable individtial variation in intestinal absorption and renal excretion of magnesium. For instance, the normal magnesium intake via food and tap water by receiving an additional $200-600 \mathrm{mg}$ magnesium, which increased serum magnesium by approximately $10 \%$ [30].

Although this result is not consistent with the tendency of magnesium to be associated with the differences in dietary intakes. This relationship provides a quantitative indication of the affinity of magnesium for a particular clinical fraction, magnesium deficiency may contribute to pathological processes [31]. Clinicians should consider using magnesium supplementation to prevent deficiency in patients at risk and to treat deficiency when it occurs. When the individual magnesium intake from food is low, e.g. $200-250 \mathrm{mg}$, then the additional daily magnesium intake in magnesium rich regions, e.g. $50 \mathrm{mg}$, may have a "cardio protective" effect while in magnesium poor regions a chronic magnesium deficiency is likely to develop [32]. 
The inability of the senescent myocardium to respond to ischemic stress could be due to several reasons. magnesium supplemented $\mathrm{K}^{+}$cardioplegia modulates $\mathrm{Ca}^{2+}$ accumulation and is directly involved in the mechanisms leading to enhanced post ischemic functional recovery in the aged myocardium following ischemia. While many of these mechanisms remain controversial and in some cases speculative, the beneficial effects related to consequences of magnesium supplementation are apparent. Further research is needed for the incorporation of these findings toward the development of novel myocardial protective role of magnesium to reduce morbidity and mortality of patients suffering from a variety of cardiac diseases.

\subsection{Conclusions}

The development of procedures for the direct analysis of magnesium in blood and serum remains a great challenge. The insufficient sensitivity and vulnerability to matrix interferences of these technique can be overcome by the addition of $2 \%(\mathrm{w} / \mathrm{v}) \mathrm{AlCl}_{3} \cdot 6 \mathrm{H}_{2} \mathrm{O}$ which was responsible for the disappearance of phosphate interference. Since the method described in this study gave correct results for magnesium, it can be used for the direct determination of magnesium in whole blood and serum .Results obtained for magnesium levels in whole blood and serum show that a direct inversely correlation observed between magnesium levels and ischemic heart disease patients, and a significance difference observed between magnesium levels and the sex of individuals, but no correlation observed between magnesium levels and age. The data indicate that $\mathrm{Mg}$ deficiency can lead to ischemic heart disease because its essential role in a wide range of fundamental cellular reactions in patients with ischemic heart disease. Furthermore, the therapeutic value of $\mathrm{Mg}$ in the management of coronary risk factors and ischemic heart disease has been clarified. Dietary Mg supplementation should be considered as a preventive element in ischemic heart disease.

\section{Acknowledgements}

The researcher would like to thank all the staff, dectors, nurses, laboratory technician, in the Al-Sader technical hospital for their kind assistance and providing facilities during data and samples collection procedure. The authors also would like to express thanks to N. A. Awad for his helpful comments on the manuscript.

\section{References}

[1] National Research Counsil, "Diet and Health," National
Academy Press, Washington DC, 1989.

[2] S. Chakraborti, T. Chakraborti, M. Mandal, A. Mandal, S. Das and S. Ghosh, "Protective Role of Magnesium in Cardiovascular Disease: A Reiew," Molecular and Cellular Biochemistry, Vol. 238, No. 1-2, 2002, pp. 163-179. doi:10.1023/A:1019998702946

[3] N. E. Saris, E. Mervaala, H. Karppanen, J. A. Khawaja and A. Lewenstam, "Magnesium. An Update on Physiological, Clinical and Analytical Aspects," Analytica Chimica Acta, Vol. 294, No. 1-2, 2000, pp. 1-26.

[4] G. E. Burch and T. D. Giles, "The Importance of Magnesium Deficiency in Cardiovascular Disease," American Heart Journal, Vol. 94, No. 5, 1977, pp. 649-657. doi:10.1016/S0002-8703(77)80137-3

[5] P. C. Elwood and W. H. Beasley, "Myocardial Magnesium and Ischaemic Heart Disease," Artery, Vol. 9, 1981, pp. 200-204.

[6] I. Bersohn, "Atherosclerosis and Coronary Heart Disease: Possible Incrimination of Magnesium Deficiency in Their Promotion," Medical Procedures, Vol. 4, 1958, p. 62.

[7] M. S. Seelig, "Possible Roles of Magnesium in Disorders of the Aged," In: R. W. Gelson and F. M. Sinex, Eds., "Intervention in the Aging Process. Part A: Quantitation, Epidemiology," Clinical Research, AR Liss, Inc, New York, 1983, pp. 279-305.

[8] J. G. Wang, "Analysis of Clinical Biochemistry," Hunan Scientific \& Technological Publishing Company, Changsha, 1980.

[9] "Analytical Methods for Flame Spectroscopy," Varian Techtron Pty. Limited, Mulgrave, 1979.

[10] P. W. Sunderman and F. Boerner, "Normal Values in Clinical Medicine," Saunders, Philadelphia, 1950.

[11] W. S. Spector, "Handbook of Biological Data," Wright Air Development Center, New York, 1956.

[12] R. Elin, "Laboratory Tests for Assessment of Magnesium Status in Humans," Magnesium and Trace Elements, Vol. 10, 1991-1992, pp. 172-181.

[13] E. B. Flink, J. E. Brick and S. R .Shane, "Alterations of Long-Chain Free Fatty Acid and Magnesium Concentrations in Acute Myocardial Infarction," Archives of Internal Medicine, Vol. 141, No. 4, 1981, pp. 441-443. doi:10.1001/archinte.1981.00340040037014

[14] E. B. Flink, S. R. Shane, R. R. Scobbo, N. G. Blechschmidt and P. McDowell, "Relationship of Free Fatty Acids and Magnesium in Ethanol Withdrawal in Dogs," Metabolism, Vol. 28, No. 8, 1979, pp. 858-865. doi:10.1016/0026-0495(79)90213-0

[15] D. A. Elliott and M. A. Rizack, The Journal of Biological Chemistry, Vol. 249, 1973, pp. 3985-3990.

[16] H. Ebel and T. Günther, "Role of Magnesium in Cardiac Disease," Journal of Clinical Chemistry \& Clinical Biochemistry, Vol. 21, 1983, pp. 249-265

[17] M. Haigney, B. Silver, E. Tanglao, H. Silverman, D. Hill, E. Shapiro, G. Gerstenblith and S. Schulman, "Nonivasive Measurement of Tissue Magnesium and Correlation with Cardiac Levels," Circulation, Vol. 92, 1995, pp. 
2190-2197.

[18] H. Rasmussen, P. Aurup, S. Hojberg, K. Jensen and P. McNair, "Magnesium and Acute Myocardial Infarction," Archives of Internal Medicine, Vol. 146, No. 5, 1986, pp. 872-874. doi:10.1001/archinte.1986.00360170068010

[19] M. R. England, G. Gordon, M. Salem and B. Chernow, "Magnesium Administration and Dysrhythmias after Cardiac Surgery. A Placebo-Controlled, Double-Blind, Randomized Trial," JAMA, Vol. 268, No. 17, 1992, pp. 2395-2402. doi:10.1001/jama.1992.03490170067027

[20] R. S. Parsons, T. C. Butler and E. P. Sellars, "Hardness of Local Water Upplies and Mortality from Cardiovascular Disease," Lancet, Vol. 278, No. 7195, 1961, p. 213. doi:10.1016/S0140-6736(61)90505-0

[21] P. M. Savenkov, A. K. Martynov, G. I. Kertsman, O. B. Bobrooskaya and A. D. Pogorelsky, "The Use of Magnesium Composition in Patients with Atherosclerosis of Vessels of the Heart, Brain, and Lower Extremities," Kardiologia, Vol. 11, 1971, p. 85.

[22] R. S. Parsons, T. Butler and E. P. Sellars, "The Treatment of Coronary Artery Disease," Med. Proc., Vol. 5, 1959, p. 487.

[23] K. H. Hackethal and Z. Den, "Aussprache Vortragen I and II," Chirurgie, Vol. 35, 1951, p. 270.

[24] H. G. Heinrich, "Prophylaxe und Therapie Thrombotischer Zustande Mit Magnesium," Zschs Gesell Inn Medicine, Vol. 12, 1957, p. 777.
[25] B. Schitzler, "Thromboseprophylaxe Mit Magnesium," Munchen Medical Wochschr, Vol. 99, 1957, p. 81.

[26] J. Durlach, "Pilule et Thrombose (des Plaquettes,des Estrogens et du Magnesium)," Reviews Franclin Endocninology Clinical, Vol. 11, No. 45, 1970.

[27] N. G. Ardlie, E. E. Nisizawa and M. Guccione, "Effect of $\mathrm{Ca}$ and $\mathrm{Mg}$ on Platelet Function," Federation Procedures, Vol. 29, 1970, p. 423.

[28] R. S. Tonks, "Haematology-Magnesium, Adenosine Diphosphate and Blood Platelets," Nature, Vol. 210, 1966, p. 106.

[29] M. S. Seelig, Magnesium Bull, Vol. 3, 1981, pp. 26-47.

[30] R. Fehlinger, L. Franke, E. Glatzel, E. Meyer, M. Michalik, S. M.Rapoport, M. Rüstow, C. Schulz and G. Schumann, Magnesium Bull, Vol. 3, 1981, pp. 298-306.

[31] F. Liao, A. R. Folsom, F. L. Brancati, "Is Low Magnesium Concentration a Risk Factor for Coronary Heart Disease? The Atherosclerosis Risk in Communities (ARIC) Study," American Heart Journal, Vol. 136, No. 3, 1998, pp. 480-490. doi:10.1016/S0002-8703(98)70224-8

[32] P. S. Gartside and C. J. Glueck, "The Important Role of Modifiable Diatary and Behaivioral Characteristic in the Causation and Prevention of Coronary Heart Disease Hospitalization and Mortality: The Prospective NHANES Followup Study," Journal of the American College of Nutrition, Vol. 14, 1995, pp. 71-79. 